\title{
The Influence of Human Resource Management Practices on Employee Performance in the Manufacturing Sector in Malaysia
}

\author{
Ong Choon Hee (Corresponding author) \\ Azman Hashim International Business School, \\ Universiti Teknologi Malaysia, 81310 Johor Bahru, Johor, Malaysia \\ E-mail: ongchoonhee@gmail.com \\ Koh Rui Jing \\ Azman Hashim International Business School, \\ Universiti Teknologi Malaysia, 81310 Johor Bahru, Johor, Malaysia \\ E-mail: jjingkoh@gmail.com
}

Received: Mar. 14, 2018 Accepted: Apr. 3, 2018 Online published: Apr. 4, 2018

doi:10.5296/ijhrs.v8i2.12826 URL: https://doi.org/10.5296/ijhrs.v8i2.12826

\begin{abstract}
The purpose of this study is to examine the relationship between Human Resource Management (HRM) practices (Compensation and Benefits, Work-life Policies, Performance Appraisal and Training and Development) and employee performance. Data was collected through questionnaire from 161 employees of a manufacturing company in Johor, Malaysia. The results of the multiple regression analysis showed that performance appraisal and training and development were significantly related to employee performance. The findings suggested that training and development is the most important factor that positively influences employee performance followed by performance appraisal. Compensation and benefits and work-life policies were found to be not significant in predicting employee performance. In relation to these findings, human resource department shall have designed suitable training plan with comprehensive and consistent performance appraisal system for the employees.
\end{abstract}

Keywords: employee performance, compensation and benefits, work-life policies, performance appraisal, training and development 


\section{Introduction}

\subsection{Background of the Study}

Business world is becoming more competitive with rapid change over the years; it is more unstable and unpredictable. Nevertheless, manufacturing sector has to discover and maintain its competitive advantage besides transform into creative and innovative. This can be done by focusing on HRM practices which deals with human resource capital (Sparrow, Schuler, \& Jackson, 1994). Human resource is recognized as the most important element in running a business as organizational performance including profitability is heavily dependent on employee performance (Mello, 2005). Apart from the size and nature of business, the behavior and decision of the employee was reported as the deciding factor for the success in running an organization. Hence, many successful organizations acknowledge the urgency to employ human resource practices in performance evaluation since the employee performance is improved eventually if the HR practices were improved. Caliskan (2010) suggested that HR practices of an organization can be its competitive advantage. This is because the human capital can be used to improve $4 \mathrm{M}$ which are material, machine, money and methods and the most critical reason is that human resources vary among organizations; it is unique and inimitable (Shaukat, Ashraf, \& Ghafoor, 2015). According to Zheng and Lamond (2010), inefficiency of Human Resource Management Practices is the most significant determinant of employee performance. Besides that, HR practices are also concluded to have positive correlation with employee's performance (Qureshi et.al. 2007). There are many researchers conducted systematic studies to investigate the relationship between HRM practices and employee's performance and most of them found out that the impact of HRM practices on employee's performance is remarkable (Arthur 1994; Huselid in 1995; MacDuffie, 1995; Guest, 1997). According to Boselie et.al. (2005), there were 104 research studies considered HRM as a set of employee management practices. Therefore, successful organizations believe that HRM practices are the determinants that influence the employee's performance. In the developing economies, to sustain the growth of an organization, a new paradigm of HR practices is needed in order to attract and retain the knowledge workers as these qualified professional have new perception towards their career (Khilji, 2002) Most importantly, employee performance has direct correlation with performance of the organization. However, many of the previous studies examined the impacts of HRM practices on employee performance among teachers and those who work in banking industry. This study specifically investigates the effects of HRM practices on employees' performance in a manufacturing company at which the findings of this study is helpful for manufacturing industry to understand the influence of HRM practices on employee performance by examining the variables. This study is helpful in future studies related to HRM practices and employee performance especially in the Malaysian context.

\section{Literature Review}

\subsection{Employee Performance}

The use of knowledge, skills, experiences and abilities to complete the mission assigned in an effective and efficient way is known as employee's performance (Dubrin, 2006). Employee 
performance helps to take the cost of resources used into consideration (Mathis \& Jackson, 2004), assess the quantity and quality of work performed (Mathis \& Jackson, 2004), survive and outshine among firms (Lee \& Carter, 2011), measure and achieve preset performance goals and lastly improve the efficiency of the employee performance for decision making (Boysen, Demery, \& Shake, 1999). The evaluation of employee performance is based on several criteria such as employee attributes, employee behavior and employee achievement (Kaplan, 2003). Many researchers claimed that organizational performance is positively affected by Human resource management practices (Huselid, 1995; Sun, Aryee, \& Law, 2007; Liao, Toya, Lepak, \& Hong, 2009). Nevertheless, Huselid (1995) proposed that there was no concrete evidence to support this presumption. Good organizational performance relies on employee's involvement as suggested by different researchers. Besides that, employee's attitude is the determining factor when translating HRM policies and practices into specific performance (Ramsay, Scholarios, \& Harley, 2000; Nishii, L., 2008). An employee with good performance is motivated by intrinsic motivation and encouragement. These high performers boost up organizational performance. That is the reason why most of the research on human resource practice is conducted in employees' perspective (Bowen \& Ostroff, 2004; Nishii \& Wright, 2008). The strategy and contextual circumstances of an organization is shown through the way of implementation of HR management system as the pattern of human resource capital management depends on the organization's decision. This pattern reveals the information sharing between the organization and the employees (Bretz \& Judge, 1994). The existence of difference between managers and non-managers in the aspect of perceptions creates gap among managers and non-managers regarding the influence of human resource practice on employee's performance. Therefore, research for seeking perceptive agreement between these two parties on human resource practice is necessary (Nishii \& Wright, 2008 ). Organizational performance is highly dependent on the employee performance and successful organization agrees that human resource contributes to performance (AL-Qudah, Osman, Ab Halim, \& Al-Shatanawi, 2014). HRM practices are implemented for employee's performance evaluation and in this highly competitive era, improve HRM practices could have boost up employee performance (Caliskan, 2010; Bowra, Z. et.al, 2012).

\subsection{Human Resource Management Practices}

Schuler and Jackson (1987) described HRM as organizational activities for talent pool management with the motive of resources are utilized aligning with organizational goal. According to them, HRM consists of various practices and its associated functions could be used for managing people in the organizations. Besides that, definition offered by Delery and Doty (1996) stated that HRM contributes to the achievement of business objectives by having an internally rational policies and practices designed for firm's human capital. HRM practices included recruitment, appraisal and selection of perspective employees at which influencing the human resource policies and lastly provide direction for the development of human resource philosophies as a whole in an organization. HRM practices acts as the backbone of the organization structure and its main responsibility is to transform the operational system into modern system in order to fulfil present requirements and needs regardless of the rapid technological development (Priyadarshini \& Venkatapathy, 2005). On top of that, HR 
practitioner better focuses on system approach rather than implement specific practices (Lepak, Bartol, \& Erhardt, 2005). Furthermore, HRM practices complement each other and it is better to be looked from an integrated perspective for a more comprehensive and holistic view (Lepak and Snell, 1999; Lepak et al., 2005). According to Purcell (2003), employee commitment is positively influenced by the HRM practices. HRM needs can be identified within the context of organizational objectives through HRM planning and many kinds of micro-staffing can be introduced for meeting the needs as long as the needs are identified and understood in advance (Montgomery, 1998; Heraty and Morley, 1998; Paul and Anantharaman, 2003). Saha and Gregar (2012) revealed that HRM acts as the backbone of any business for better competitive advantage as these competitive practices are designed for productivity enhancement and has driven the knowledge development process in the aspect of knowledge transfer.

\subsection{Compensation and Benefits}

Compensation is a process of offering monetary value to employees for the effort they directed in their tasks performed. Employee compensation and benefits is described as any form of pay, monetary rewards, bonuses, commissions, leaves, recognition programs, flexi work hours and medical insurance (Sherman \& Snell, 1998). Another description of compensation is any form of monetary returns including the intangible service and benefits that paid to an individual (Milkovich \& Newman, 1999). Bergmann and Scarpello (2001) described that compensation system is useful in enhancing the efforts of promotes output towards the company's objectives accomplishment. Besides that, compensation is also supposed to incur the highest cost in running a business. In the same vein, compensation system acts as motivation tool for enhancing job performance (Chiu, Luk, \& Tang, 2002) . Many past studies have clearly established the roles of compensation and benefits in affecting performance of employees. Compensation system which based on excellence is the most effective HRM practice as it encourages high level performance of employees. Besides that, compensation system which based on performance is claimed as the best indicator in measuring the performance of employee at both individual and group level (Osterloh, Frey, \& Homberg, 2007 ). Likewise, Dubrin (2006) concluded that the employees tend to get motivated for perform job task efficiently if their pay is linked with the performance measurement at individual or group level. A study conducted by Huselid (1995) showed a noteworthy relationship between compensations and employee performance. According to Wright, (2003), the effective integration of performance and compensation can enhance the efficiency of employee. On top of that, Ahmad and Shahzad (2011) found that the performance of university teachers will go up if compensation is enhanced and Mohammad A. Al Qudah, Osman, \& M. Al. Qudah (2014) revealed that compensation has positive effect with employee performance. On top of that, Hassan (2016) concluded a significant relationship between compensation and employee's performance. Therefore, based on the above explanation, it is hypothesized that,

H1: There is a positive relationship between compensation and benefit and employee performance. 


\subsection{Work-life Policies}

Work-life policies are similar to working environment with low conflict between work and family issue at which the needs of the employees are taken into account by the organizations (Honeycutt and Rosen 1997; Kopelman et al. 1983). Work-life balance policies are properly designed and practiced at the organizational level, normally by HR directors or managers. On the other hand, Work-life balance programs were introduced with the intention of facilitating employees for better integration and management in work and family responsibilities (De Cieci et al., 2005) at which intended to help employees cut down the levels of stress, conflict of work- family, and create more positive output between work and family (Thompson \& Prottas, 2006; Glass \& Finley, 2002; Rupert et al, 2009). Kopelman, Ptottas, Thompson, and White Jahn (2006) investigated the relationship between work-life balance program and positive attitudes and behaviors at the HR manager and employee levels. They concluded that the more work-life balance programs offered, the better the commitment and perceived organizational family support. According to Konrad and Mangel (2000), Work Life Balance program in 195 firms created significant positive impact on productivity if large portion of workforce were women and when professional was employed (McConville \& Holden, 1999; Parris et al., 2008; Purcell \& Hutchinson, 2007; Ryan \& Kossek, 2008). With work-life balance policies, employees could have less stress, minimum work-family conflict and more positive output between work and family (Thompson \& Prottas, 2006; Glass \& Finley, 2002; Rupert et al, 2009). In a study of 55 firms, the company representative stated that the employee productivity is maintained when the administrative employees are allowed to bring their children to work during unexpected occurrence such as childcare arrangements broke down (Secret, 2006). Therefore, based on the above explanation, it is hypothesized that,

$\mathrm{H} 2$ : There is a positive relationship between work-life policies and employee performance.

\subsection{Performance Appraisal}

Performance appraisal is described as a formalistic process at which monitor the work and evaluate the performance of employee regularly. It is also used as a management tool for improving the employee performance and productivity and minimizes the error rate (Daley, 1992; Brown and Heywood, 2005). Performance appraisal is the fundamental element of human resource management; almost all of the HR decisions are made based on the results of the appraisal (Brown et al, 2010). Performance appraisal is also known as employee evaluation; it is important not only for the advancement of the employees but also crucial for the operation of organizations (Francis X. \& Brian H., 1994) and (Boice \& Kleiner, 1997). In an organization, the identification of people for the leading position is normally done by rating the employees. Proper reviewing the employees' work and reward appropriately is necessary as it helps to acknowledge the efforts of employee. It is complicated and difficult in implementing performance appraisal system because the appraisal must be accurate and fair for all employees. Arbaiy and Suradi (2007) proposed that managers can assess the efficiency of employee in the aspects of resources management within the organization through performance appraisal and then this creates competitive advantages amongst employees. According to Kelly et al (2008), it is over 80 percent of the respondents in the study wants 
appraisal system and 45 percent of the respondents wish to have improvement on their current appraisal system. As per stated in the study, an appropriate appraisal system with fairness and clarity resulting satisfaction, performance development, motivation and perception towards performance bonuses. On top of that, the well-managed appraisal system aids the identification of essential job competencies and encourages the professional growth in competitiveness and innovation. It was proposed that the evaluation of employee shall not focus on the personality characteristics and general traits factors but on the job related performance. Boice and Kleiner (1997) suggested that committed and motivated employees are the "product" of effective appraisal system. Therefore, many researchers urge that an effective appraisal system shall be accurate, measurement system which evidently defined, with good record keeping and most importantly is with regular review of performance. Moreover, the communication between employee and supervisor can be smoother if the objectives are defined with full consultation between two parties. Therefore, based on the above explanation, it is hypothesized that,

H3: There is a positive relationship between performance appraisal and employee performance.

\subsection{Training and Development}

Training and development has three main activities such as training individuals, educating internal customers and lastly their development. Training can either on the training and development pertaining to regular work task which given by superior or the vocational training which given off the job. Training and development is a planned process which let employee expose to new knowledge and acquire new skills and technologies in order to maintain or improve the performance in the workplace. Therefore, training is one of the crucial HRM practices especially successful organizations (Robbins S. P., 2003). Kuballa (2007) suggested that the investment on workforce is actually for the organization's own benefit as the trained workforces have higher productivity and contribute to higher organizational effectiveness and such organization is capable to attract workforce with higher quality. Furthermore, timely training helps to increase the adaptability and flexibility of workforce, ensure the employees acquire high level of skill and at the same time develop the knowledge and positive attitudes in order to maintain the competitive advantage (Schuler \& MacMillan, 1984; Sherman \& Snell, 1998; Hale, 2005). Training and development can be used to enhance employee's capability, help the employee to achieve the lifelong career capability and promote the organization commitment towards achievement of company's goals (Paré \& Tremblay, 2007 ). Samuel and Chipunza (2009) reported that training and development is known as the most crucial tool for every employee to expose and acquire new knowledge and skills in order to maintain the performance in this highly competitive work environment. Furthermore, Arthur et al. (2003) concluded that training has positive effect on job-related behaviors or performance. Moreover, Khalid, Rahman, \& Ilyas (2014) and Sattar, Ahmad, \& Hassan (2015) proposed that training showed positive and significant effect on employee performance. Hassan (2016) concluded that training plays a positive role in increasing employee's performance. Therefore, based on the above explanation, it is hypothesized that, 


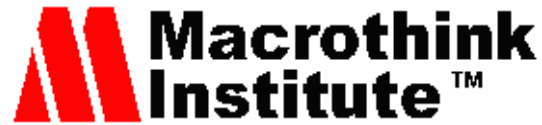

International Journal of Human Resource Studies

ISSN 2162-3058

2018, Vol. 8, No. 2

H4: There is a positive relationship between training and development and employee performance.

\section{Methodology}

\subsection{Participants}

This study was conducted in the selected manufacturing company in Malaysia. A total of 161 Malaysian employees participated in the study, which is composed of 81 males $(50.3 \%)$ and 80 females (49.7\%). Most of the respondents were Malay (65.8\%), and majority of the respondents were aged between 31 and 40 years old (41.6\%). In terms of academic qualifications, 84 (52.2\%) respondents are SPM holders. Then, 34 and 26 of the respondents are Bachelor degree and Diploma holders respectively. 15 of the other respondents $(9.3 \%)$ are SRP/PMR holder and only minority of them (2 respondents) is Master degree holder. Majority of the participants fall in the categories of 6-10 and 11-15 years of service; 22 respondents or $13.7 \%$ for each category. The second highest number is 36 at which their length of service is between 1 to 5 years; 38 respondents or $23.6 \%$. Then, $18.6 \%$ of respondents are less than 1 year of service.

\subsection{Method and Instruments}

This study employed quantitative method. The samples were generated through simple random sampling technique. The employee performance scale (10 items) was adapted from Salfi (2010) and Williams \& Anderson (1991). For compensation and benefits, measures (5 items) by Heneman \& Schwab (1985) were used in the study. Meanwhile, work-life policies were measured by instruments (5 items) adapted from Guy \& Michel (2000). 5 items of measurement developed by Chang (2005) \& Rogg et al. (2001) were employed to measure performance appraisal of the respondents and measures for training and development were adapted from Edgar and Geare (2005). Likert scale was used to measure the level of agreement for employee performance and the respective human resource management (HRM) practices. The scale was anchored by 1 (Strongly Disagree), 2 (Disagree), 3 (Neutral), 4 (Agree) and 5 (Strongly Agree).

\subsection{Data Analysis}

In this study, Factor Analysis is performed for both the dependent and independent variables to identify the validity of the measurement scales of the instrument upon the data collection for the actual survey have completed. Methods employed for data analyses are reliability test, correlation analysis and multiple regression analysis. Statistical Package for Social Sciences (SPSS) software is used to analyse the data obtained.

\section{Results}

\subsection{Factor Analysis}

The results from 161 respondents were carefully analyzed and output results are described in this section. The Factor Analysis was conducted by employing Principal Component Analysis (PCA) in order to analyze the validity of the test. The construct validity was tested using 


\section{MInstitute ${ }^{\text {Mink }}$}

International Journal of Human Resource Studies

ISSN 2162-3058

2018, Vol. 8, No. 2

Bartlett's Test of Sphericity and KMO/MSA test indicated the strengths among the variables.

Table 1 and Table 2 illustrated the results of the factor analysis. The results indicate that the value of Kaiser-Meyer-Olkin for Measuring of Sampling Adequacy (KMO/MSA) was 0.776 for independent variable and 0.893 for dependent variable, the employee performance. According to Hutcheson and Sofroniou (1999), values of KMO/MSA between 0.7 and 0.8 are good for factor analysis. Next, the Bartlett's test of Sphericity was found statistically significant at $\mathrm{p}<.001$ and thus supported the factorability of the correlation matrix. Principal component analysis revealed that there were 4 factors with strong loadings. Factor 1 was labelled as performance appraisal (4 items), Factor 2 was named as compensation and benefit (4 items), Factor 3 was identified as Factor 3 was identified as training and development (4 items) and Factor 4 was named as work-life policies (3 items). Based on the Factor Analysis results in Table 1, performance appraisal, compensation and benefit, training and development and work-life policies have contributed $30.398 \%, 15.730 \%, 10.774 \%$ and $9.470 \%$ of the common variance respectively with Eigenvalues of 4.560, 2.359, 1.616 and 1.421. The four factors cumulatively captured $66.371 \%$ of the variance. The factor loading values of the scale were in the range of 0.357 to 0.866 .

Table 1. Factor Analysis and Reliability Test for the HRM Practices

\begin{tabular}{|c|c|c|c|c|c|}
\hline Item & Description & & Factor & ading & \\
\hline & & 1 & 2 & 3 & 4 \\
\hline pa16 & $\begin{array}{l}\text { Performance appraisals are based on } \\
\text { objective and quantifiable results. }\end{array}$ & 0.759 & & & \\
\hline pa17 & $\begin{array}{l}\text { The performance review process is } \\
\text { linked to compensation plans. }\end{array}$ & 0.793 & & & \\
\hline pa18 & $\begin{array}{l}\text { The performance review process is } \\
\text { standardized and documented. }\end{array}$ & 0.771 & & & \\
\hline pa19 & $\begin{array}{l}\text { Promotions and pay increases are } \\
\text { based on achieving documented } \\
\text { performance objectives. }\end{array}$ & 0.849 & & & \\
\hline cb6 & I am satisfied with my current salary. & & 0.866 & & \\
\hline cb7 & $\begin{array}{l}\text { I am satisfied with the amount the } \\
\text { company pays for my benefits. }\end{array}$ & & 0.856 & & \\
\hline cb8 & $\begin{array}{l}\text { I am satisfied with the raises I have } \\
\text { received in the past. }\end{array}$ & & 0.798 & & \\
\hline cb9 & $\begin{array}{l}\text { I am satisfied with my benefit } \\
\text { package. }\end{array}$ & & 0.717 & & \\
\hline $\operatorname{td} 21$ & $\begin{array}{l}\text { My employer encourages me to } \\
\text { extend my abilities. }\end{array}$ & & & 0.698 & \\
\hline $\operatorname{td} 22$ & $\begin{array}{l}\text { This organization has provided me } \\
\text { with training opportunities enabling } \\
\text { me to extend my range of skills and } \\
\text { abilities. }\end{array}$ & & & 0.766 & \\
\hline $\operatorname{td} 23$ & $\begin{array}{l}\text { I get the opportunity to discuss my } \\
\text { training and development } \\
\text { requirements with my employer. }\end{array}$ & & & 0.805 & \\
\hline $\operatorname{td} 24$ & $\begin{array}{l}\text { My work pays for any work-related } \\
\text { training and/or development I want } \\
\text { to undertake. }\end{array}$ & & & 0.782 & \\
\hline wlp11 & $\begin{array}{l}\text { Managers allow generally enough } \\
\text { time for the completion of projects }\end{array}$ & & & & 0.357 \\
\hline
\end{tabular}


so that employee can do good quality work with limited stress.

\begin{tabular}{llrrc}
\hline wlp13 & $\begin{array}{l}\text { My work schedule is not in conflict } \\
\text { with my personal life. }\end{array}$ & & 0.859 \\
\hline wlp14 & $\begin{array}{l}\text { My job does not affect my role as a } \\
\text { spouse and/or a parent. }\end{array}$ & & & 0.847 \\
\hline Eigenvalue & 30.390 & 2.359 & 1.616 & 1.421 \\
\hline Percentage of Common Variance (\%) & 30.398 & 15.730 & 10.774 & 9.470 \\
\hline Cumulative Percentage (\%) & 30.398 & 46.127 & 56.901 & 66.371 \\
\hline Reliability Coefficient (Cronbach's Alpha) & 0.844 & 0.607 & 0.838 & 0.803 \\
\hline
\end{tabular}

Note. $\mathrm{KMO}=0.776$, Bartlett's test of Sphericity: Approx.Chi-Square=990.606, $\mathrm{p}<.001$.

Table 2 shows a scale factor of employee performance that consists of 10 items. Principal component analysis extracted and found that all items are still with 10 original factors. Cumulative percent for all items is 49.885 , as shown in the table.

Table 2. Factor Analysis for Employee Performance

\begin{tabular}{clc}
\hline Item & \multicolumn{1}{c}{ Description } & Factor Loading \\
\hline ep_26 & $\begin{array}{l}\text { I complete my job accurately and timely to achieve the } \\
\text { work objective. }\end{array}$ & 0.717 \\
\hline ep_27 & $\begin{array}{l}\text { I meet work hours schedule and attendance } \\
\text { expectations. }\end{array}$ & 0.522 \\
\hline ep_28 & $\begin{array}{l}\text { I able to identify, analyze problems and find solution } \\
\text { for it. }\end{array}$ & 0.793 \\
\hline ep_29 & $\begin{array}{l}\text { I deal confidently and efficiently with top management } \\
\text { and colleagues. }\end{array}$ & 0.740 \\
\hline ep_30 & $\begin{array}{l}\text { I demonstrate necessary knowledge and skills to } \\
\text { perform the job effectively. }\end{array}$ & 0.819 \\
\hline ep_31 & $\begin{array}{l}\text { I establish my job objectives with regard to the } \\
\text { department and company goals. }\end{array}$ & 0.761 \\
\hline ep_32 & $\begin{array}{l}\text { I am capable of completing my task within the time } \\
\text { frame. }\end{array}$ & 0.540 \\
\hline ep_33 & I volunteer to complete extra tasks. & 0.546 \\
\hline ep_34 & I produce high quality work. & 0.792 \\
\hline ep_35 & I complete duties according to procedures. & 4.989 \\
\hline & Eigenvalue & 0.893 \\
\hline & Kercentage of Variance Explained & 695.380 \\
\hline & Bartlett's Test of Sphericity & 0.877 \\
\hline
\end{tabular}

Note. KMO=0.893, Bartlett's test of Sphericity: Approx.Chi-Square=695.380, p<.001.

Factors having eigen values greater than one are considered significant as shown in Table 2. When the eigen values is less than 1.0, this means that the factor explains less information than a single item would have explained. These statistical results confirmed the validity of measurement scales used for this study as shown in Table 1 and Table 2.

\subsection{Reliability Test}

The reliability test results of independent variables and dependent variables were indicated in Table 1 and Table 2 respectively. The reliability coefficient (Cronbach's Alpha) for 


\section{Macrothink}

International Journal of Human Resource Studies

ISSN 2162-3058

2018, Vol. 8, No. 2

independent variables namely performance appraisal, compensation and benefit and training and development was rated 0.838, 0.844 and 0.803 respectively. Cronbach's Alpha value for dependent variable, employee performance is 0.877 . All the measures were deemed reliable and consistent throughout the study as all values have exceeded the minimum value of 0.7 as suggested by Nunnally (1978) and DeVellis (2003) except the variable of work-life policies. The Cronbach's Alpha value for work-life policies is 0.607. According to Kerlinger (1973), any measurement instrument should have reliability value more than 0.60 . However, George and Mallery (2003) argue that only Cronbach's Alpha value below 0.5 is considered unacceptable even though the ideal value is above 0.7. Therefore, variable of work-life policies is considered as moderately reliable. These statistical results confirmed the reliability of measurement scales used for this study as shown in Table 1 and Table 2.

\subsection{Correlation Analysis}

Pearson correlation analysis was employed to examine the correlation between employee performance and the independent variables namely compensation and benefits, work-life policies, performance appraisal and training and development respectively. The result in Table 3 indicates a correlation between the dependent variable and independent variables. The result show that training and development with the value $r=0.493$ and $\operatorname{sig}=0.000(p<0.01)$ has the strongest correlation with employee performance among four variables and both compensation and benefits $(\mathrm{r}=0.229$, sig $=0.004(\mathrm{p}<0.01))$ and work-life policies $(\mathrm{r}=0.310$, sig $=0.000(\mathrm{p}<0.01))$ are weakly correlate with employee performance. Based on the test result of this correlation, performance appraisal with the value $r=0.420$ and sig $=0.000$ $(p<0.01)$ has moderate correlation with employee performance.

Table 3. Correlation between Human Resource Management Practices and Employee Performance

\begin{tabular}{|c|c|c|c|c|c|}
\hline & $\begin{array}{c}\text { Compensation } \\
\text { and } \\
\text { Benefits }\end{array}$ & $\begin{array}{l}\text { Work-life } \\
\text { Policies }\end{array}$ & $\begin{array}{c}\text { Performance } \\
\text { Appraisal }\end{array}$ & $\begin{array}{c}\text { Training } \\
\text { and } \\
\text { Development }\end{array}$ & $\begin{array}{c}\text { Employee } \\
\text { Performance }\end{array}$ \\
\hline $\begin{array}{l}\text { Compensation } \\
\text { and Benefits }\end{array}$ & 1 & & & & \\
\hline $\begin{array}{l}\text { Work-life } \\
\text { Policies }\end{array}$ & $.295 * *$ & 1 & & & \\
\hline $\begin{array}{c}\text { Performance } \\
\text { Appraisal }\end{array}$ & $.170^{*}$ & $.283 * *$ & 1 & & \\
\hline $\begin{array}{l}\text { Training and } \\
\text { Development }\end{array}$ & $.278 * *$ & $.261 * *$ & $.409 * *$ & 1 & \\
\hline $\begin{array}{c}\text { Employee } \\
\text { Performance }\end{array}$ & $.229 * *$ & $.310^{* *}$ & $.420 * *$ & $.493 * *$ & 1 \\
\hline
\end{tabular}

**. Correlation is significant at the 0.01 level (2-tailed). 
*. Correlation is significant at the 0.05 level (2-tailed).

\subsection{Multiple Regression Analysis}

Table 4 shows that Multiple Linear Regression Analysis among Independent Variable and Employee Performance. The analysis shows that 32.3 percent $\left(\mathrm{R}^{2}=0.323\right)$ of the variance employee performance can be explained by the four chosen human resource management practices. The analysis shows that training and development has a significant positive relationship with employee performance $(\beta=0.348, \mathrm{p}<0.001)$. This means that the more training program the employee attends, the higher the employee performance. Besides that, performance appraisal $(\beta=0.229, \mathrm{p}<0.01)$ also has significant positive relationship with employee performance. The performance appraisal system could have encouraged the employee to strive for better performance. However, the regression results of the present study indicated that training and development of the workers contributed more in employee performance than that of performance appraisals. Therefore, hypothesis $\mathrm{H} 3$ and $\mathrm{H} 4$ that proposed positive relationship between variables are accepted. Referring to Table 4, there is no significant relationship between compensation and benefit and employee performance with the value $\beta=0.052$ and sig=0.465 ( $>0.01)$. Therefore, hypothesis H1 is rejected. Also, there is no significant relationship between work-life policies and employee performance with the value $\beta=0.139$ and sig=0.055 ( $\mathrm{p}>0.05$ ). Therefore, hypothesis $\mathrm{H} 2$ is also rejected.

Table 4. Multiple Regression Analysis among Independent Variable and Employee Performance

\begin{tabular}{cccccccc}
\hline \multirow{2}{*}{$\begin{array}{c}\text { Independent } \\
\text { Variable }\end{array}$} & \multicolumn{2}{c}{$\begin{array}{c}\text { Employee } \\
\text { Performance }\end{array}$} & & & \multirow{2}{*}{ Hypothesis } & Result \\
\cline { 2 - 5 } & beta, $\beta$ & Sig. & Tolerance & VIF & & \\
\hline $\begin{array}{c}\text { Compensation } \\
\text { and Benefit }\end{array}$ & 0.052 & 0.465 & 0.869 & 1.150 & $\mathrm{H} 1$ & Rejected \\
\hline $\begin{array}{c}\text { Work-life } \\
\text { Policies }\end{array}$ & 0.139 & 0.055 & 0.846 & 1.181 & $\mathrm{H} 2$ & Rejected \\
\hline $\begin{array}{c}\text { Performance } \\
\text { Appraisal }\end{array}$ & $0.229 * *$ & 0.002 & 0.799 & 1.251 & $\mathrm{H} 3$ & Accepted \\
\hline $\begin{array}{c}\text { Training and } \\
\text { Development }\end{array}$ & $0.348^{* * *}$ & 0.000 & 0.778 & 1.286 & $\mathrm{H} 4$ & Accepted \\
\hline F value & & & \multicolumn{7}{c}{18.586} & & \\
\hline R Square & & & 0.32 & & \\
\hline
\end{tabular}

$* * *$ Significant at the 0.001 level, ** Significant at the 0.01 level, * Significant at the 0.05 level

\section{Discussion}

HRM practices such as training and development and performance appraisal statistically influence the employee performance at higher rates. On the other hand, compensation and benefits and work-life policies indicated insignificant influences. First of all, Collins and Clark (2003) suggested that most of the companies used performance-based compensation in terms of rewarding employees and this is supported by Brown et al. (2003) at which performance-based compensation has positive influence on employee's performance. Nevertheless, the results of this study are in contrast to the expectations as the findings 
indicate that compensation and benefits have no significant relationship with employee performance. In the selected manufacturing company, the employees perceived that compensation and benefits have nothing to do with their performance level since the compensation and benefits is dependent on length of service or in another word; the compensation and benefits are based on the seniority of the employee but not performance. No differentiation is made based on how well a person performs a job but it depends only on how long the person has been in the job. Secondly, the result of this study shows that work-life policies have no significant relationship with employee performance. This supports the findings by previous researchers that the availability of formal organizational policies has no positive relation with employee productivity (Thompson, 2006). Also, the study findings indicate that there is a significant positive relationship between performance appraisal and employee performance. This is because in an organization, the identification of people for the leading position is normally done by rating the employees. Hence, proper reviewing the employees' work and reward appropriately is necessary as it helps to acknowledge the efforts of employee. Furthermore, this research affirmed the proposition that training and development has a positive impact on employee performance. The declarative or procedural and strategic knowledge of employees could be enhanced if they are provided with appropriate training sessions. Employee who has developed this knowledge exhibits higher consistency of performance across conditions if compared to others. The study is fruitful as it successfully gains the attention of those employees in manufacturing sector towards the importance and influence of HRM practices on their level of performance. The findings suggest that a combination of inclusive training and development policies and a comprehensive performance appraisal system could have improved the employee performance. The survey should be conducted among the employees from time to time to evaluate their level of performance with the current practices and line managers should be involved in the process of designing or modifying the HRM practices. In addition, government should enforce standardized, consistent and uniform policies in all business sectors, agencies or subsidiaries in practicing HRM policies. Government agencies like Small and Medium Industries Development Corporation (SMIDEC), and other government agencies should create better awareness of the benefits of HRM practices to encourage higher level of employee performance in the business organization.

\section{Limitations and Future Study}

There is limitation associated with this study. In setting the parameters for this research, the focus was placed solely in manufacturing organizations and the sample size for Malaysian manufacturing sector in this study were obtained only within the Malaysian employees in the southern region of the country. Therefore, the result may not able to generalize the overall manufacturing industry in Malaysia as other companies might have different kinds of Human Resource Management practices and working climate. In future, the study of relationship between HRM practices and employee performance can be more comprehensive where it covers the central and northern regions of the county within the manufacturing sector. 


\section{Conclusion}

The study has enhanced the fact that HRM practices generate positive impact on employee performance in the organization. Based on the findings of this empirical research, training and development has the strongest impact on employee performance, followed by performance appraisal. The current data has provided employer sufficient evidence for the human resource department of the organization in designing the best suitable solutions for improving the employee performance. Nevertheless, the immediate solutions might not applicable for long term objective in talent management because the employees' performance is heavily influenced by ability, motivation and opportunity which are changing rapidly with development of technology. On top of that, the direction of organization, the internal policy and external competitive environment of the business also influence the expectation of employees. It is very important for the organization to take note that enhancing employee performance using HRM practices is a big issue for the development of an organization especially it might bring destructive effects to the organizational efficiency if it was not properly designed and implemented.

\section{Acknowledgements}

The authors wish to thank the Malaysian Ministry of Higher Education and Universiti Teknologi Malaysia (Vot: 14J81) for providing financial support to publish this paper.

\section{References}

Ahmad, S., \& Shahzad, K. (2011). HRM and employee performance: A case of university teachers of Azad Jammu and Kashmir (AJK) in Pakistan. African Journal of Business Managem, 5(13), 5249-5253.

AL-Qudah, M., Osman, A., Ab Halim, M., \& Al-Shatanawi, H. (2014). The Effect of Human Resources Planning and Training and Development on Organizational Performance in the Government Sector in Jordan. International Journal of Academic Research, 4(4).

Arbaiy, N., \& Suradi , Z. (2007). Staff performance appraisal using fuzzy evalaution. International Federation for Information Processing, 247, 195-203. https://doi.org/10.1007/978-0-387-74161-1_21

Arthur, J. (1994). Effects of human resource systems on manufacturing performance and turnover. Academy of Management journal, 37(3), 670-687. https://doi.org/10.2307/256705

Arthur, W., Bennett, W., Edens, P., \& Bell, S. (2003). Effectiveness of training in organizations: A meta-analysis of design and evaluation features. The Journal of Applied Psychology, 88, 234-245. https://doi.org/10.1037/0021-9010.88.2.234

Bergmann, T. J., \& Scarpello, V. G. (2001). Compensation Decision Making (4th ed.). Harcourt: Fort Worth, TX.

Boice, F. D., \& Kleiner, H. B. (1997). Designing effective performance appraisal systems. Work Study, 46(6), 197-201. https://doi.org/10.1108/00438029710367622

Boselie, P., Dietz, G., \& Boon, C. (2005). Commonalities and contradictions in HRM and 
performance research. Human Resource Management Journal, 15, 67-94. https://doi.org/10.1111/j.1748-8583.2005.tb00154.x

Bowen, D., \& Ostroff, C. (2004). Understanding HRM-firm performance linkages: The role of the — strength\| of the HRM system. Academy of Mannagement Review, 29, 203-221.

Bowra, Z., Sharif, B., Saeed, A., \& Niazi, M. (2012). Impact of human resource practices on employee perceived performance in banking sector of Pakistan. African Journal of Business Management, 6(1), 323-332.

Boysen, C., Demery, A., \& Shake, S. (1999). Achieving Organizational excellence through the performance measurement system: Consortium benchmarking study-best practice report. Houstan, TX: American Productivity Center.

Bretz, \& Judge. (1994). The role of human resource systems in job applicant decision processes. Journal of Management, $20, \quad$ 531-551. https://doi.org/10.1177/014920639402000301

Brown, M., \& Heywood, J. (2005). Performance appraisal systems: determinants and change. British Journal of Industrial Relations, 43(4), 659-679. https://doi.org/10.1111/j.1467-8543.2005.00478.x

Brown, M., Hyatt, D., \& Benson, J. (2010). Consequences of the performance appraisal experience. Personnel Review, 39(3), 375-396. https://doi.org/10.1108/00483481011030557

Brown, T., \& Benson, P. A. (2003). The Company and the Product-Corporate associations and consumer product responses. Journal o $f$ Marketing, 61, 68-85. https://doi.org/10.2307/1252190

Caliskan, N. E. (2010). The impact of strategic human resource management on organizational performance . Journal Naval Science Engineering , 6(2), 100-116.

Chang, E. (2005). Employee's overall perception of HRM effectiveness. Human Relations, 58(4), 523-544. https://doi.org/10.1177/0018726705055037

Chiu, R. K., Luk, V. W., \& Tang, T. (2002). Retaining and Motivating Employees: Compensation Preferences in Hong

Collins, C. J., \& Clark, K. (2003). Strategic human resource practices, top management team social networks, and firm performance: The role of human resource practices in creating organizational competitive advantage. Academy of management Journal, 46(6), 740-751. https://doi.org/10.2307/30040665

Daley, D. (1992). Performance Appraisal in the Public Sector: Techniques and Applications. ABC-CLIO.

De Cieri, H., Holmes, B., Abbott, J., \& Pettit, T. (2005). Achievements and challenges for work/life balance strategies in Australian organizations. International Journal of Human Resource Management, 16(1), 90-103. https://doi.org/10.1080/0958519042000295966 


\section{Macrothink}

International Journal of Human Resource Studies

ISSN 2162-3058 2018, Vol. 8, No. 2

Delery, J., \& Doty, D. H. (1996). Modes of theorizing in strategic human resource management: Tests of universalistic, contingency, and configurational performance predictions. Academy of Management Journal, 39(4), 802-835. https://doi.org/10.2307/256713

DeVellis, R. F. (2003). Scale development: Theory and applications $\left(2^{\text {nd }}\right.$ ed.), California: Sage.

Dubrin, A. (2006). Fundamentals of Organizational Behavior (4th ed.). United States of America: South-Western College Pub.

Edgar, F., \& Geare, A. (2005). HRM practise and employee attitudes: Difference measures and different results. Personnel Review, 34(5), 534-549. https://doi.org/10.1108/00483480510612503

Francis X., G., \& Brian H., K. (1994). Factors that Bias Employee Performance Appraisals. Work Study, 43(3), 10-13.

George, D., \& Mallery, P. (2003). SPSS for Windows step by step: A simple guide and reference. 11.0 update (4th ed.). Boston: MA: Allyn \& Bacon.

Glass, J. L., \& Finley, A. (2002). Coverage and effectiveness of family-responsive workplace policies. Human Resource Management Review, 12, 313-337. https://doi.org/10.1016/S1053-4822(02)00063-3

Guest, D. E. (1997). Human resource management and performance: a review and research agenda. International journal of human resource management, 8((3)), 263-276. https://doi.org/10.1080/095851997341630

Guy, P., \& Michel, T. (2000). The measurement and antecedents of turnover intention among IT professionals. Scientific Series, Montreal, September 2000, 1-38.

Hale, J. (2005). Pfeiffer essential resources for training and HR professionals. John Wiley and Sons..

Hassan, S. (2016). Impact of HRM Practices on Employee's Performance. International Journal of Academic Research in Accounting, Finance and Management Sciences, 6(1), 15-22. https://doi.org/10.6007/IJARAFMS/v6-i1/1951

Heneman, H. G., \& Schwab, D. P. (1985). Pay satisfaction: Its multidimensional nature and measurement. International Journal of Psychology, 20(2), 129-141.

Heraty, N., \& Morley, M. (1998). In search of good fit:policy and practice in recruitment and selection in Ireland. Journal of Management Development, 17(9), 662-685. https://doi.org/10.1108/02621719810244490

Honeycutt, T., \& Rosen, B. (1997). Family Friendly Human Resource Policies, Salary Level, and Salient Identity as Predictors of Organizational Attraction. Journal of Vocational Behaviour, 271-290, 271-290. https://doi.org/10.1006/jvbe.1996.1554 
Huselid, M. A. (1995). The impact of human resource management practices on turnover productivity, and corporate financial performance . Academy of Management Journal , 635-672. https://doi.org/10.2307/256741

Hutcheson, G., \& Sofroniou, N. (1999). The multivariate social scientist. London, United Kingdom: Sage. https://doi.org/10.4135/9780857028075

Ilic, P. (2015, May 6). Linkedin. Retrieved from Rewards and Recognition: https://www.linkedin.com/pulse/rewards-recognition-petar-ilic?trkSplashRedir=true\&forceN oSplash=true

Kaplan, R. (2003). Politics: Why Leadership Demands a Pagan Ethos. Vintage. ISBN 0-375-72627-6.

Kelly KO, Ang SYA, Chong WL, Hu WS (2008) Teacher appraisal and its outcomes in Singapore primary schools. Journal of Educational Administration 46 (1), 39-54. https://doi.org/10.1108/09578230810849808

Kerlinger, F. N., \& Pedhazur, E. J. (1973). Multiple regression in behavioral research. New York: Holt, Rinehart and Winston.

Khalid, M. M., Rahman, C. A., \& Ilyas, D. M. (2014). HRM Practices and Employee Performance in Public Sector Organizations in Pakistan: An Empirical Study. International Journal of Management Sciences and Business Research, 3(2).

Khilji, S. (2002). Modes of convergence and divergence: An integrative view of multinational practices in Pakistan. International Journal of Human Resource Management, 13(2), 232-253. https://doi.org/10.1080/09585190110102350

Konrad, A. M., \& Mangel, R. (2000). The impact of work-life programs on firm productivity. $\begin{array}{llllll}\text { Strategic } \quad \text { Management } & \text { Journal, } & 21(12), & 1225- & 1239 .\end{array}$ https://doi.org/10.1002/1097-0266(200012)21:12<1225::AID-SMJ135>3.0.CO;2-3

Kopelman, R. E., Ptottas, D. J., \& Thompson, C. A. (2006). A multilevel examination of work-life practices: Is more always better? . Journal of Managerial Issues, XVIII((2)), $232-253$.

Kopelman, R., Greenhaus, J., \& Connolly, T. (1983). A Model of Work, Family, and Interrole Conflict: A Construct Validation Study. Organizational Behavior and Human Performance, 32, 198-215. https://doi.org/10.1016/0030-5073(83)90147-2

Kuballa, J. (2007). Employee satisfaction- A precondition for economic success of service companies? GRIN Verlag.

Lee, K., \& Carter, S. (2011). Global marketing management. Strategic Direction, 27(1). https://doi.org/10.1108/sd.2011.05627aae.001

Lepak, D. P., \& Snell, S. (1999). The human resource architecture: Toward a theory of human capital allocation and development. Academy of Management Review, 24, 31-48. 
Lepak, D., Bartol, K., \& Erhardt, N. (2005). A contingency framework for the delivery of HR practices. Human Resource Management Review, 15, 139-159. https://doi.org/10.1016/j.hrmr.2005.06.001

Liao, H., Toya, Lepak, \& Hong. (2009). Do they see eye to eye? Management and employee perspectives of high-performance work systems and influence processes on service quality. Journal of Applied Psychology, 94, 371-391. https://doi.org/10.1037/a0013504

MacDuffie, J. (1995). Human resource bundles and manufacturing performance: Organizational logic and flexible production systems in the world auto industry. Industrial labor relations review, 48((2)), 197-221. https://doi.org/10.1177/001979399504800201

Mathis, H., \& Jackson, L. (2004). Human Resource Management. Singapore: Thomson Asia Pte .Ltd.

McConville, T., \& Holden, L. (1999). The filling in the sandwich: HRM and middle managers in the health sector. Personnel Review, 28(5\&6), 406-424. https://doi.org/10.1108/00483489910286738

Mello, J. (2005). Strategic Human Resource Management (2nd ed.). South-Western College.

Milkovich, G., \& Newman, J. M. (1999). Compensation. New York: Irwin McGraw-Hill.

Mohammad A. Al_Qudah, H., Osman, D. A., \& M. Al. Qudah, H. E. (2014). The Effect Of Human Resources Management Practices On Employee Performance. International Journal of Scientific \& Technology Research, 3(9), 129-134.

Montgomery, S. (1998). Implications of the severity of social phobia. Journal of Affective Disorders, 50(1), 18-22. https://doi.org/10.1016/S0165-0327(98)00093-7

Nishii, L. H., \& Wright, P. M. (2008 ). Variability Within Organizations: Implications for Strategic Human Resource Management. In D.B. Smith (Ed.), The people make the place. Mahwah, NJ: Lawrence Erlbaum, 225-248 .

Nunnally, J. (1978). Psychometric Theory. New York: Mcgraw-Hill.

Osterloh, M., Frey, B. S., \& Homberg, F. (2007 ). Performance Evaluation and Pay for Performance: Does it Really Motivate Public Officials . EGPA Conference (pp. 1-18 ). Madrid: University of Zurich.

Paré, G., \& Tremblay, M. (2007 ). The Influence of High-Involvement Human Resources Practices,Procedural Justice, Organizational Commitment, and Citizenship Behaviors on Information Technology Professionals' Turnover Intentions. Eastern Academy of Management, 1-38. https://doi.org/10.1177/1059601106286875

Parris, M. A., Vickers, M., \& Wilkes, L. (2008). Caught in the middle: Organizational impediments to middle managers' work-life balance. Employment Responsibilities and Rights Journal, 101-117, 101-117. https://doi.org/10.1007/s10672-008-9069-Z

Paul, A., \& Anantharaman, R. (2003). Impact of people management practices on 
organizational performance: analysis of a causal model. International Journal of Human Resource Management, 14(7), 1246-1266. https://doi.org/10.1080/0958519032000145648

Priyadarshini, R. R., \& Venkatapathy, R. (2005). Performance and HRD: A Study among Various Types of Banks. South Asia Journal of Management, 12(3).

Purcell, J. (2003). Understanding the People and Performance Link, Unlocking the Black Box (CIPD).

Purcell, J., \& Hutchinson, S. (2007). Front-line managers as agents in the HRM-performance causal chain: Theory, analysis and evidence. Human Resource Management Journal, 17((1)), 3-20. https://doi.org/10.1111/j.1748-8583.2007.00022.x

Qureshi, T. M., Ramay I, M., \& Marwat A, Z. (2007). Impact of Human Resource Management (HRM) Practices on Employees Performance.

Ramsay, H., Scholarios, D., \& Harley, B. (2000). Employees and highperformance work systems: Testing inside the black box. British Journal of Industrial Relations, 38, 501-531. https://doi.org/10.1111/1467-8543.00178

Robbins, S. P. (2003). Organisational Behaviour: Global and Southern African Perspectives. Pearson South Africa.

Rogg, K. L., Schmidt, D. B., Shull, C., \& Schmitt, N. (2001). Human resources practices, organizational climate and customer satisfaction. Journal of Management, 27(4), 431-449. https://doi.org/10.1177/014920630102700403

Rupert, P., Stevanovic, P., \& Hunley, H. (2009). Work-family conflict and burnout among practicing psychologists. Professional Psychology: Research and Practice, 40, 54-61. https://doi.org/10.1037/a0012538

Ryan, A., \& Kossek, E. (2008). Work-life policy implementation: Breaking down or creating barriers to inclusiveness. Human Resource Management, 47((2)), 295-310. https://doi.org/10.1002/hrm.20213

Saha, N., \& Gregar, A. (2012). Human Resource Management: As a Source of Sustained Competitive Advantage of the Firms. International Proceedings of Economics Development and Research, 46(1), 01-05. https://doi.org/10.7763/ipedr

Salfi, N. A. (2010). Successful leadership practices of head teachers for school improvement: some evidence from Pakistan. Journal Of Educational Administration, 49(4), 414 - 432. https://doi.org/10.1108/09578231111146489

Samuel, M. O., \& Chipunza, C. (2009). Employee retention and turnover: using motivational variables as a panacea. African Journal of Business Management, 3(8), 410-415.

Sattar, T., Ahmad, K., \& Hassan, S. M. (2015). Role of Human Resource Practices in Employee Performance and Job Satisfaction with Mediating Effecr of Employee Engagement. Pakistan Economic and Social Review, 53(1), 81-96. 
Schuler, R. S., \& MacMillan, I. C. (1984). Gaining competitive advantage through human resource management practices. Human Resource Management, 23(3), 241-255. https://doi.org/10.1002/hrm.3930230304

Schuler, R., \& Jackson, S. (1987). Linking competitive strategies and human resource management practices. Academy of Management Executive, 1(3), 207-229. https://doi.org/10.5465/AME.1987.4275740

Secret, M. (2006). Integrating paid work and family work. Community, Work and Family, 9(4), 407-427. https://doi.org/10.1080/13668800600925027

Shaukat, H., Ashraf, N., \& Ghafoor, S. (2015). Impact of Human Resource Management Practices on Employees Performance. Middle-East Journal of Scientific Research 23(2), 329-338.

Sherman, B., \& Snell, A. (1998). Managing Human Resources, incentives and rewards. Ohio: International Publishing.

Sparrow, P., Schuler, R. S., \& Jackson, S. E. (1994). Convergence or divergence: Human resource practices and policies for competitive advantage worldwide. The International Journal of Human Resource Management, 5(2), 267-299. https://doi.org/10.1080/09585199400000019

Sun, L., Aryee, \& Law. (2007). Sun, Aryee, \& Law,High-performance human resource practices, citizenship behavior, and organizational performance: A relational perspective. Academy of Management Journal, 50, 558-577. https://doi.org/10.5465/AMJ.2007.25525821

Thompson, C. A., \& Prottas, D. (2006). Relationships among organizational family support, job autonomy, perceived control, and employee well-being. Journal of Occupational Health Psychology, 11(1), 100-118. https://doi.org/10.1037/1076-8998.10.4.100

Williams, L. J., \& Anderson, S. E. (1991). Job satisfaction and organizational commitment as predictors of organizational citizenship and in-role behaviors. Journal of Management, 17, 601-617. https://doi.org/10.1177/014920639101700305

Wright, P. (2003). The human resource-firm performance relationship: Methodological and theoretical challenges, A Guide to the Human Impact of Modern Working Practices. London: John Wiley and Sons.

Zheng, C., \& Lamond, D. (2010). Organizational determinants of employee turnover for multinational companies in Asia. Asia Pacific Journal of Management, 27(3), 423-443. https://doi.org/10.1007/s10490-009-9159-y

\section{Copyright Disclaimer}

Copyright for this article is retained by the author(s), with first publication rights granted to the journal.

This is an open-access article distributed under the terms and conditions of the Creative Commons Attribution license (http://creativecommons.org/licenses/by/4.0/). 